\title{
Experimental investigation of butanol gasoline blends effect on the mass fraction burned in a spark ignition engine
}

\author{
I.M. Yusri1*, Shahrul Azmir Osman2, R. Mamat1, Omar .I Awad1 and S. M. Rosdi1 \\ 1Faculty of Mechanical Engineering, Universiti Malaysia Pahang (UMP). 26600 Pekan, Pahang, Malaysia \\ 2Department of Energy and Thermo-fluid, Faculty of Mechanical and Manufacturing Engineering, Universiti \\ Tun Hussein Onn Malaysia 86400 Batu Pahat, Johor, Malaysia \\ *Corresponding author email: m.yusri890@gmail.com
}

\begin{abstract}
The growing energy demand and the limitation of the fossil fuels force the transportation sector to seek for alternative energy sources. Butanol has emerged as one of the potential alternative energy solution especially for spark ignition engines. Experimental study on engine combustion characteristics particularly on mass fraction burned (MFB) of spark ignition engines fueled with secondary butyl alcohol (sec-butanol) gasoline blends was carried out. Engine was operated at engine speeds 3500 RPM with $50 \%$ of wide throttle open (WTO) for each blend $(5 \%, 10 \%$ and $15 \%$ volume of sec-butanol) and neat gasoline. The in-cylinder pressure data were collected and the average cycle was integrate to obtain MFB profiles. Based on the MFB results at using sec-butanol gasoline blends is always taken higher value of degree of crank angle compared to gasoline fuels. However, throughout the analysis, by addition of $15 \%$ of volume in gasoline fuels reduced the $10-90 \%$ early flame propagation, $10-90 \%$ combustion duration and early position of degree of crank angle at $50 \%$ of MFB for $1.7 \%$, $4.5 \%$ and $5.9 \%$ respectively with respect ot gasoline fuels.
\end{abstract}

Index Terms - sec-butanol, gasoline fuels (G100), mass fraction burned (MFB)

\section{INTRODUCTION}

Energy security is an increasing critical issues due to the potential of fossil fuels dearth in near future [1]. As in consequences, the global energy consumption brings adverse effect toward environment and human health [2]. In 2013 , the most consumed energy came from non-renewable energy which accounted for $82.67 \%$ among other energy sources in which crude oil, coal and natural gas by $30.92 \%, 28.95 \%$ and $22.81 \%$ respectively [3]. The petroleum fuels play a key factor especially in transportation area to meet the basic necessity of human needs. In order to combat the scarcity of petroleum fuels particularly in transportation areas a more efforts need to be done to find clean and sustainable alternative fuel [4].

Gasoline engines are mostly the best choices for private and commercial used [5]. The use of oxygenated fuels in gasoline engines has a great potential of reducing the dependency of the petroleum fuels [6]. The main oxygenated alternative fuel used is alcohols mainly from ethanol for operation of gasoline-type vehicles [7]. However, for the past few years, the investigation of ethanol has received considerable critical attention with less attention paid to the butanol as a sustainable alternative fuel.

Butanol is consider as an advanced alternative biofuel $[8,9]$. Butanol is a four carbon atom alcohol with chemical formula of $\mathrm{C}_{4} \mathrm{H}_{10} \mathrm{O}$ [10]. There are four types of butanol isomers categorized as n-butanol, secbutanol, tert-butanol and iso-butanol [11,12]. Each butanol is recognized based on their hydroxyl attached to one of the carbon atoms [13]. Each of these isomers have different physical and chemical properties [14]. As compared to ethanol, butanol is the most similar fuel properties to the gasoline fuel such as lower heating value, stoichiometric air-fuel ratio, research octane number and auto ignition temperature, thus, making it more appropriate to be blended with gasoline fuels [15-17].

In recent years, there has been an increasing amount of literature on butanol application used as the fuel substitutes to the gasoline fuels. Alasfour [18] studied the emission particularly on $\mathrm{NO}_{\mathrm{x}}$ emissions using of $30 \%$ by volume of butanol blended with gasoline fuels. Irimescu [16] used $50 \%$ by volume of iso-butanol mixed with gasoline fuels to investigate the effects of fuel conversion efficiency. It was find out that a slight improvement of fuel conversion efficiency up to $6 \%$ when the engine was operated by the blended fuels compared to gasoline fuels. Pechout [19] evaluated the effect of higher level butanol blends by $30 \%$ and $50 \%$ on combustion characteristics of an unmodified gasoline engines. Based on their results, flame combustion propagation was quicker with butanol blended fuels.

The importance of mass fraction burned analysis is to provide a useful account of how the combustion develop through several stages. There are three stages of the mass fraction burned: (1) flame development angle; (2) Rapid burning angle; and (3) overall burning angle [20]. The literature has emphasized the 
importance of analysis of mass fraction burned using various alternative fuels. In an analysis of mass fraction burn, Smith et al. [21] found that addition of hydrogen of approximately $25 \%$, resulted to higher peak of the mass fraction burned. However they also noted that at higher mass fraction burned the knock phenomenon occurred. Similarly, Szwaja et al. [22] found that combustion knock phenomenon are due to greater peak of the mass fraction burn. Bonatesta et al. [23] had develop an empirical function for the 0 to 90 per cent mass fraction burned to define according to Wiebe function.

The present study was designed to determine the effects of sec-butanol gasoline blends by $5 \%, 10 \%$ and $15 \%$ by volume of sec-butanol in gasoline fuels towards combustion characteristics particularly on mass fraction burned (MFB) analysis. This work contributes to extend existing knowledge of combustion characteristics of the blended fuels by sec-butanol. This investigation will performed particularly on; mass fraction burned, 0 $10 \%$ MFB, $50 \%$ and $10-90 \%$ MFB.

\section{A. Materials}

\section{EXPERIMENTAL SETUP}

Gasoline RON 97 denoted as G100 was selected as the reference fuels and analytical grade of secondary butyl-alcohol (sec-butanol) with purity of $99.5 \%$ was used in this study. Sec-butanol was mixed with reference fuels using mechanical automatic stirrer in the ratio of $5 \%, 10 \%$ and $15 \%$ by volume of sec-butanol, which are referred as GBu5, GBu10 and GBu15 respectively. Table I lists the main properties of sec-butanol and gasoline fuels.

TABLE I. PROPERTIES OF GASOLINE AND SEC-BUTANOL [24, 25, 8]

\begin{tabular}{lll}
\hline \hline Property & Gasoline & Sec-butanol \\
\hline Molar $\mathrm{C} / \mathrm{H}$ ratio & $0.44-0.50$ & - \\
$\begin{array}{l}\text { Density }\left(\mathrm{g} / \mathrm{cm}^{3} \text { at } 20^{\circ} \mathrm{C}\right) \\
\text { Lower heating value }(\mathrm{KJ} / \mathrm{kg})\end{array}$ & $0.72-0.76$ & 806.3 \\
Stoichiometric air/fuel ratio & 14.6 & 33,000 \\
RON/MON & $95 / 85$ & 11.1 \\
$\begin{array}{l}\text { Auto - ignition temperature } \\
\left({ }^{\circ} \mathrm{C}\right)\end{array}$ & $228-470$ & $401 / 32$ \\
$\begin{array}{l}\text { Boiling point }\left({ }^{\circ} \mathrm{C}\right) \\
\begin{array}{l}\text { Heat of vaporization } \\
(\mathrm{KJ} / \mathrm{Kg})\end{array}\end{array}$ & $27-225$ & 99.5 \\
$\begin{array}{l}\text { Flammable limits } \\
(\% \text { volume })\end{array}$ & 349 & 551 \\
Laminar flame speeds $[26]$ & $\sim 33$ & $1.4-7.6$ \\
\hline \hline
\end{tabular}

\section{B. Description of experimental setup}

Experiments were conducted on a Mitsubishi 4G93 four-cylinder, four-stroke, water-cooled, port-fuelinjection spark ignition (SI) engines using sec butanol gasoline blends as test fuel and gasoline as baseline fuel. The experiments on SI engines were conducted without making any modification in the engine hardware. The technical specifications of the test engine are given in Table II. Actual engine test bed and the schematic diagram of the experimental setup are shown in Fig. 1. The relative air fuel ratio was taken using an accurate calibrated KANE gas analyzer version autoplus 5-2. Air flow through the intake was measured using Benetech GM8903 hot wire type anemometer with the air speeds resolution by $0.001 \mathrm{~m} / \mathrm{s}$. A total of seven thermocouples was mounted at; intake exhaust, fuel line and outlet engine cooling; in order to control the engine surrounding temperatures. Engine cylinder number one was attached with the in-cylinder pressure sensor to measure instantaneously in-cylinder pressure of the engine using Kistler piezoelectric in-cylinder pressure transducer 6125B spark plug type with a measuring rate of $0-200$ bars and a sensitivity of $\sim-10 \mathrm{pC} / \mathrm{bar}$. The crank angle signal was acquired with Kistler 2613B1 crank angle encoder, and the in-cylinder combustion pressure was recorded simultaneously using DEWE-Combustion analyzer provided from DEWE-5000 series data acquisition system. It should be mentioned that the spark timing of the engine was not controlled, however throughout the analysis the spark timing occurred nearly at $0^{\circ}$ crank angle. Fuels were tested in this order: gasoline, GBu5, GBu10 and GBu15. Following each fuel change, the engine was operated for about 15 to 20 minutes at intermediate RPM using gasoline fuels. This was done to flush the fuel system to avoid fuel injector clogged especially when using sec-butanol gasoline blends. Each experiment was repeated three times and the measured 
experimental value were averaged. Tests were conducted at single engine speeds of 3500 RPM with $50 \%$ of wide throttle open. Engine speed of $3500 \mathrm{rpm}$ has been emphasize in this study since it is the regular operating engine speed for most of the engine.

TABLE II. ENGINE SPECIFICATIONS

\begin{tabular}{ll}
\hline \hline Engine Descriptions & \\
\hline Bore x Stroke & $81.0 \mathrm{~mm}$ x 89.0mm \\
Piston Displacement & $1834 \mathrm{cc}$ \\
Compression Ratio & $9.5: 1$ \\
Fuel injection type & ECI-Multi (Electronically \\
& Controlled Multi-point Fuel \\
& Injection \\
Max Power & $86 \mathrm{~kW} @ 5500 \mathrm{rpm}$ \\
Max Torque & $161 \mathrm{Nm} @ 4500 \mathrm{rpm}$ \\
\hline \hline
\end{tabular}

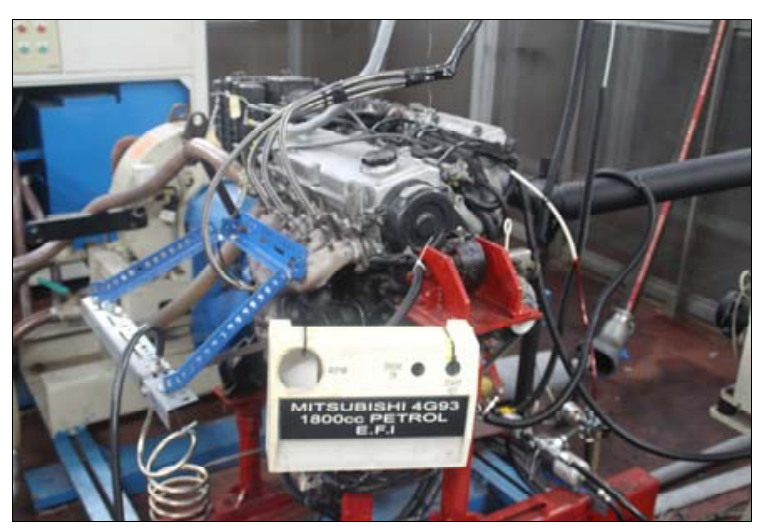

Fig. 1. Engine test bed

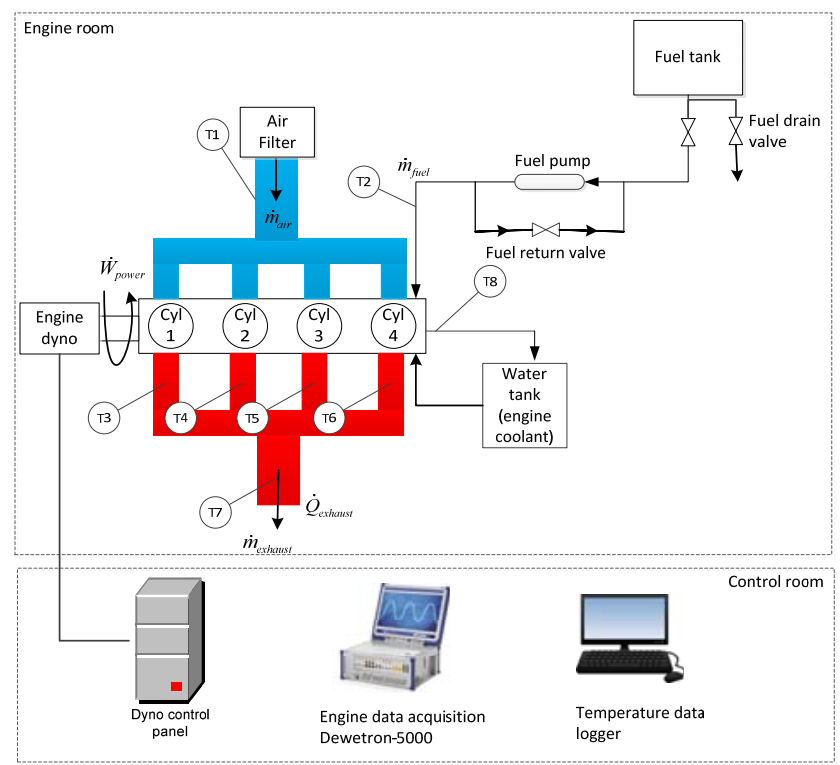

Fig. 2. Schematic diagram

\section{Mass fraction burned analysis}

Mass fraction burned (MFB) for the fuel signifies the percentage quantity of fuel that has been combusted within the cylinder in certain combustion duration [20]. Chemical energy $Q_{c h}$ released by combustion can be determine on the foundation of the first law of thermodynamics as a function of crank angle $\theta$. 
$Q_{c h}=\int_{\theta}\left(\frac{\gamma}{\gamma-1} p \frac{d V}{d \theta}+\frac{1}{\gamma-1} V \frac{d p}{d \theta}\right) d \theta$

Where $\gamma$ is the polytropic index, $p$ is the in-cylinder pressure, $V$ is the cylinder volume and $\theta$ is the engine crank angle. Mass fraction burned (MFB) in each individual engine cycle is a normalized quantity with a scale of 0 to $100 \%$, describing the process of chemical energy release as a function of crank angle. The determination of MFB is commonly based on burn rate analysis. The assumption was made that, during engine combustion, the pressure rise $\Delta p$ consists of two parts: pressure rise due combustion $\left(\Delta p_{c}\right)$ and pressure change due to volume change $\left(\Delta p_{v}\right)$ :

$\Delta p=\Delta p_{c}+\Delta p_{v}$

Assuming that the pressure rise $\Delta p_{c}$ is proportional to the heat added to the in-cylinder medium during the crank angle interval, the mass fraction burned may be calculated as:

$$
M F B=\frac{m_{b}(i)}{m_{b}(\text { total })}=\frac{\sum_{0}^{i} \Delta p_{c}}{\sum_{0}^{N} \Delta p_{c}}
$$

Where $i$ is the consider combustion interval and $N$ is the is the total number of crank intervals [27].

\section{RESUlt AND DISCUSSIONS}

In this presence research investigation, the quantity of $\mathrm{GBuX}$ represents a blend consisting of $\mathrm{X} \%$ of secbutanol by percentage of volume, e.g., GBu5 indicates a blend consisting of $5 \%$ of sec-butanol in $95 \%$ of gasoline. Four test fuels were emphasized in this study: gasoline (G100); 5\% of 2-butanol (GBu5); $10 \%$ of butanol (GBu10); and 15\% of (GBu15). In Fig. 1 indicates the normalized mass fraction burned (MFB) with respect to crank angle degree at 3500 RPM with $50 \%$ of wide throttle open (WTO). The MFB profile is a key elements of combustion for the fuel to represents the burning amount of fuel percentage combusted in the combustion chamber in certain combustion duration [28]. This parameter highly depends on the ignition delay period and peak in cylinder pressure for different tested fuels. Based on the Fig. 3, the highlighted area represents the zoom area specified at $0-10 \%, 50 \%$ and $10-90 \%$ of MFB. At all of MFB conditions it can be said that G100 fuels are the nearest to the top dead center followed by GBu15, GBu10 and GBu5.

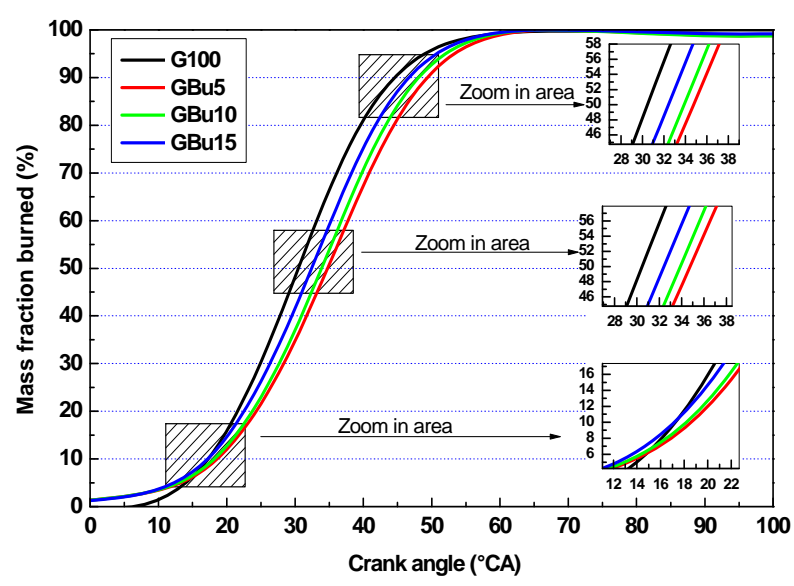

Fig. 3. Normalized mass fraction burned at 3500 RPM

Fig. 4 presents $0-10 \%$ MFB at 3500 RPM with $50 \%$ of WTO. The term $0-10 \%$ of MFB refers to early flame development of the tested fuels. Generally, blended fuels produce lower early flame development compared to G100 fuels. However with successive increases in concentration of the sec-butanol, the blended fuels early flame development tend to be shorter. Based on the calculation, the percentage differences between the blended fuels and G100 are 7.5\%, 5.5\% and 1.7\% for GBu5, GBu10 and Gbu15 respectively. It is almost certain that lower temperature of combustible mixture would result in lower reaction rate in pre-ignition phase especially for GBu5 [29]. 


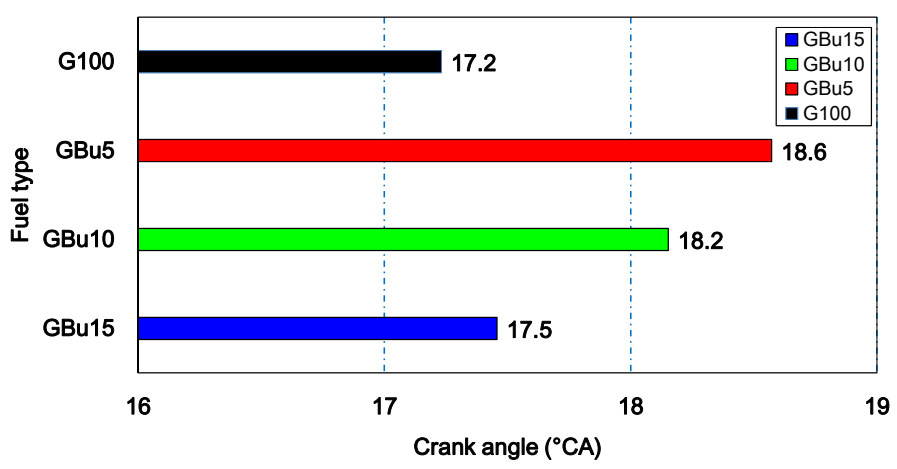

Fig. 4. $0-10 \%$ of MFB at 3500 RPM with $50 \%$ WTO

Fig. 5 shows $10-90 \%$ MFB at 3500 RPM with $50 \%$ of WTO. In the literature, the term $10-90 \%$ MFB was used to refer as combustion duration of the engines. In Fig. 6, it reveals that there gradual decline combustion duration with respect to butanol additions. It was also observed that a strong relationship between early flame development and combustion duration. Basically from both Fig. 4 and 5, longer flame propagation resulting in a higher combustion duration with respect to the crank angle degree positions. Comparing the results obtained between the blended and G100 fuels, GBu5, GBu10 and GBu15 experienced 9.7\% 7.3\% 4.5\% longer combustion duration respectively. The combustion duration produced by the blended fuels is always higher as compared with that of the G100, however there a significant positive result since the trends of combustion duration decreases with addition of sec-butanol in gasoline fuels.

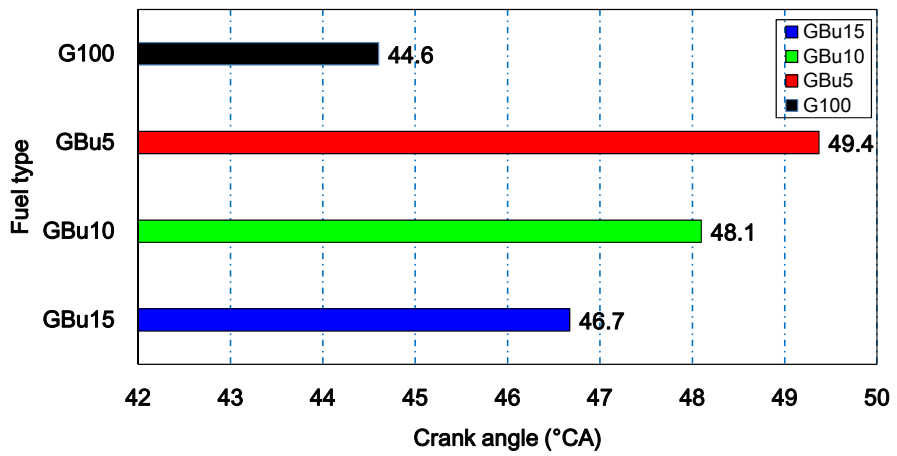

Fig. 5. $10-90 \%$ of MFB at 3500 RPM with $50 \%$ WTO

Fig. 6 indicates $50 \%$ position of MFB at 3500 RPM with 50\% of WTO. The $50 \%$ MFB denotes the center of combustion and the engine torque strongly depends on location of 50\% MFB. The location of $50 \%$ MFB of GBu15 is more advanced than that of GBu10 and GBu5, besides almost the same with G100. This is because sec-butanol produces more complete combustion due to the extra oxygen content leading to more energy input from fuel chemical reactions. Nevertheless, it was expected that if the butanol content increase more than $15 \%$, the $50 \%$ MFB position could be equivalent to G100 fuels. With respects to G100, blended fuels produced endure reductions of $50 \%$ of MFB positions by $12.3 \%, 10 \%$ and $5.9 \%$ for GBu5, GBu10 and GBu15 respectively.

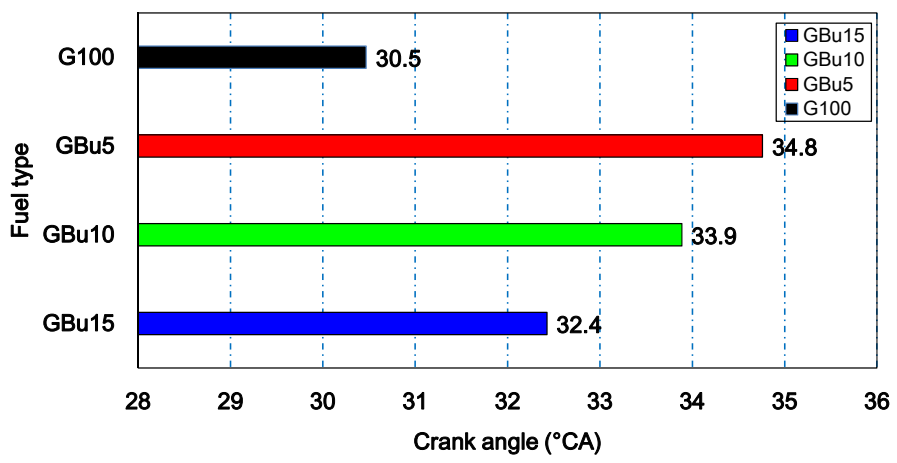

Fig. $6.50 \%$ of MFB at 3500 RPM with $50 \%$ WTO 


\section{CONCLUSION}

As biofuels role is set to play an important role in future energy security utilization, the present study was designed to determine the effect of sec-butanol gasoline blends by $5 \%, 10 \%$ and $15 \%$, by volume basis of secbutanol in gasoline fuels toward its mass fraction burned characteristics particularly on $0-10 \%$ of MFB, $10-$ $90 \%$ of MFB and $50 \%$ of MFB locations. This study has shown that all blended fuels produce lower $0-10 \%$ of MFB, $10-90 \%$ of MFB and $50 \%$ of MFB locations with respect to G100 fuels. Despite this, as the sec-butanol volume increased, the blended fuels mainly GBu10 and GBu15 exhibited shorter early flame propagation, combustion duration and 50\% of MFB locations with regards to its degree of crank angle.

\section{ACKNOWLEDGMENT}

Appreciation and acknowledgement to the Ministry of Higher Education (KPT) for providing author the scholarship under My Brain 15 schemes and financial support under Universiti Tun Hussein Onn Malaysia, Vot: U360. Sincere thanks to Mr. Muhd Hafietz Bin Yusoff for bountiful assistant in term of technical supports during the engine testing. Finally, the authors thank the anonymous referees and the editor for carefully reading this paper and suggesting many helpful comments on improving the original manuscript.

\section{REFERENCES}

[1] M. Mofijur, H. H. Masjuki, M. A. Kalam, M. A. Hazrat, A. M. Liaquat, M. Shahabuddin, et al. (2012). Prospects of biodiesel from jatropha in malaysia. Renewable and Sustainable Energy Reviews 16, 5007-5020.

[2] A. C. Hansen, Q. Zhang, and P. W. Lyne. (2005). Ethanol-diesel fuel blends -- a review. Bioresour Technol 96, 277-285.

[3] W. N. M. Wan Ghazali, R. Mamat, H. H. Masjuki, and G. Najafi. (2015). Effects of biodiesel from different feedstocks on engine performance and emissions: A review. Renewable and Sustainable Energy Reviews 51, 585-602.

[4] P. G. Aleiferis, J. Serras-Pereira, and D. Richardson. (2013). Characterisation of flame development with ethanol, butanol, iso-octane, gasoline and methane in a direct-injection spark-ignition engine. Fuel 109, 256-278.

[5] C. Berggren and T. Magnusson. (2012). Reducing automotive emissions - the potentials of combustion engine technologies and the power of policy. Energy Policy 41, 636-643.

[6] Y. Varol, C. Öner, H. Öztop, and Ş. Altun. (2014). Comparison of methanol, ethanol, or n-butanol blending with unleaded gasoline on exhaust emissions of an si engine. Energy Sources, Part A: Recovery, Utilization, and Environmental Effects 36, 938-948.

[7] S. K. Thangavelu, A. S. Ahmed, and F. N. Ani. (2016). Review on bioethanol as alternative fuel for spark ignition engines. Renewable and Sustainable Energy Reviews 56, 820-835.

[8] C. Jin, M. Yao, H. Liu, C.-f. F. Lee, and J. Ji. (2011). Progress in the production and application of n-butanol as a biofuel. Renewable and Sustainable Energy Reviews 15, 4080-4106.

[9] N. Qureshi and T. C. Ezeji. (2008). Butanol,'a superior biofuel'production from agricultural residues (renewable biomass): Recent progress in technology. Biofuels, Bioproducts and Biorefining 2, 319-330.

[10] I. M. Yusri, M. K. Akasyah, R. Mamat, and O. M. Ali. (2015). Combustion and emissions characteristics of a compression ignition engine fuelled with n-butanol blends. Jurnal Teknologi (Science and Engineering) 77, 69-73.

[11] B. W. Weber and C.-J. Sung. (2013). Comparative autoignition trends in butanol isomers at elevated pressure. Energy \& Fuels 27, 1688-1698.

[12] I. Yusri, R. Mamat, W. Azmi, G. Najafi, N. Sidik, and O. I. Awad. (2016). Experimental investigation of combustion, emissions and thermal balance of secondary butyl alcohol-gasoline blends in a spark ignition engine. Energy Conversion and Management 123, 1-14.

[13] I. M. Yusri, R. Mamat, O. M. Ali, A. Aziz, M. Akasyah, M. K. Kamarulzaman, et al. (2016). The combustion of n-butanol-diesel fuel blends and its cycle to cycle variability in a modern common-rail diesel engine. Journal of Engineering and Applied Sciences 11, 2297-2301.

[14] S. Kumar, J. H. Cho, J. Park, and I. Moon. (2013). Advances in diesel-alcohol blends and their effects on the performance and emissions of diesel engines. Renewable and Sustainable Energy Reviews 22, 46-72.

[15] Z. Chen, Z. Wu, J. Liu, and C. Lee. (2014). Combustion and emissions characteristics of high n-butanol/diesel ratio blend in a heavyduty diesel engine and egr impact. Energy Conversion and Management 78, 787-795.

[16] A. Irimescu. (2012). Performance and fuel conversion efficiency of a spark ignition engine fueled with iso-butanol. Applied Energy 96, 477-483.

[17] A. Uyumaz. (2015). An experimental investigation into combustion and performance characteristics of an hcci gasoline engine fueled with n-heptane, isopropanol and n-butanol fuel blends at different inlet air temperatures. Energy Conversion and Management 98, 199-207.

[18] F. Alasfour. (1999). The effect of using 30\% iso-butanol-gasoline blend on hydrocarbon emissions from a spark-ignition engine. Energy Sources 21, 379-394.

[19] M. Pechout, M. Mazac, and M. Vojtisek-Lom. (2012). Effect of higher content n-butanol blends on combustion, exhaust emissions and catalyst performance of an unmodified si vehicle engine. Sae Technical Paper 1.

[20] J. B. Heywood, Internal combustion engine. New York: Mc Graw Hill, 1988.

[21] S. Szwaja and K. Grab-Rogalinski. (2009). Hydrogen combustion in a compression ignition diesel engine. international journal of hydrogen energy $34,4413-4421$.

[22] S. Szwaja, K. Bhandary, and J. Naber. (2007). Comparisons of hydrogen and gasoline combustion knock in a spark ignition engine. international journal of hydrogen energy 32, 5076-5087.

[23] F. Bonatesta, B. Waters, and P. Shayler. (2010). Burn angles and form factors for wiebe function fits to mass fraction burned curves of a spark ignition engine with variable valve timing. International Journal of Engine Research 11, 177-186.

[24] M. K. Balki and C. Sayin. (2014). The effect of compression ratio on the performance, emissions and combustion of an si (spark ignition) engine fueled with pure ethanol, methanol and unleaded gasoline. Energy 71, 194-201.

[25] X. Gu, Z. Huang, J. Cai, J. Gong, X. Wu, and C.-f. Lee. (2012). Emission characteristics of a spark-ignition engine fuelled with gasoline-n-butanol blends in combination with egr. Fuel 93, 611-617.

[26] K. Nithyanandan, H. Wu, M. Huo, and C.-F. Lee. (2014, ). A preliminary investigation of the performance and emissions of a port-fuel injected si engine fueled with acetone-butanol-ethanol (abe) and gasoline. SAE International 1. 
[27] A. S. Krzysztof Z. Mendera, Michał Smereka (2002). Mass fraction burned analysis Journal of KONES Internal Combustion Engines.

[28] O. M. ALI, "The influence of additives on biodiesel blend for engine performance and emission improvement " Doctor of Philosophy, Mechnical Engineering, Universiti Malaysia Pahang, 2014.

[29] B. Deng, J. Fu, D. Zhang, J. Yang, R. Feng, J. Liu, et al. (2013). The heat release analysis of bio-butanol/gasoline blends on a high speed si (spark ignition) engine. Energy 60, 230-241. 